\title{
MEASURING DEMOCRATIC ACCOUNTABILITY: AN INITIAL REPORT ON AN EMERGING DATA SET
}

\author{
Midiendo responsabilidad democrática: Reporte Inicial \\ sobre una emergente base de datos
}

\section{HERBERT KITSCHELT, KENT FREEZE, KIRIL KOLEV, YI-TING WANG}

Duke University

\begin{abstract}
In this paper, we report on a new dataset based on expert surveys carried out in nearly 90 countries around the world. This dataset helps to overcome the limited existence of cross-national data on democratic linkage mechanisms between citizens and politicians, especially with regard to contingent exchange of targeted goods for electoral support as most studies that have examined democratic accountability have a narrow geographic focus or are single-case studies. The report outlines the various methodological challenges faced in implementing the survey and in interpreting its results, as well as steps taken to determine the quality of the data. This preliminary analysis of results from the survey lends support that the various indicators developed from the survey are reliable and valid measures of political parties' actual organizational practices, linkage mechanisms, and policy orientations.
\end{abstract}

Key words: Democratic Accountability, Clientelism, Expert Survey, Party Competition.

\section{RESUMEN}

En este trabajo reportamos sobre una nueva base de datos de encuestas a expertos, cursadas en más de 90 países de todo el mundo. Esta base de datos ayuda a superar la ausencia de información comparable entre países en torno a los mecanismos democráticos de relación entre ciudadanos y políticos; los modos como éstos proveen bienes específicos coyunturales a cambio de apoyos electorales. Además, evita una limitación que caracteriza a la mayoría de los estudios anteriores sobre rendición de cuentas en un contexto democrático: su reducido enfoque geográfico y el hecho de ser estudios de casos particulares. El reporte arroja luz sobre los desafíos metodológicos enfrentados en el proceso de implantación de la encuesta e interpretación de sus resultados. Asimismo destaca los pasos tomados para determinar la calidad de la información. Este análisis preliminar de los resultados de la encuesta permite afirmar que los indicadores desarrollados son fiables y válidos para medir las prácticas organizacionales de los partidos políticos, sus mecanismos de relación con el electorado y sus orientaciones programáticas.

Palabras Clave: “Rendición de Cuentas" clientelismo, encuesta a expertos, competición partidaria. 
This paper reports on data collected for a project on modes of democratic accountability in polities with a modicum of democratic electoral competition for office around the world, based on information collected for a total of 86 out of 89 countries for which the data collection process has been completed ${ }^{1}$. The purpose is to introduce the dataset and evaluate the quality of the data and the validity of the concepts studied prior to engaging in substantive comparative investigations to test theoretical propositions. In terms of the data quality, we think that this data project is high-risk and poses great challenges not to over-tax weak data and draw erroneous conclusions not borne out by the evidence. Here we discuss the outline of strategies to probe into the quality of the data. Our paper marks only the beginning and a number of the steps outlined here need to be pursued in the future. But our critics may come up with other techniques to probe into data quality we have not thought of and we will be eager to embrace in our future work.

The paper is organized in seven sections. First, we lay out the theoretical motivations for exploring democratic accountability and linkages between politicians and citizens in democratic polities. We then turn to the options we considered when it comes to conducting research on clientelistic linkage and the research strategy we ultimately chose. In the third section, we discuss the methodological challenges associated with the approach to data collection employed in the project. In the fourth part of the paper, we take a first systematic look at the data and the information we have on party policy positions across various dimensions. We then focus on exploring the data on party organization and action, again at the party level. Next we examine variation and patterns in terms of targeted exchange and monitoring (clientelism) and discuss how the findings we get there are consistent or not with other questions elsewhere in the survey. Finally, we conclude with a short section examining how our measures for programmatic and clientelistic competition relate to other variables outside the dataset, such as economic development or quality of democracy.

\section{THE THEORETICAL TOPIC: DEMOCRATIC ACCOUNTABILITY AND CITIZEN-POLITICIAN LINKAGE IN DEMOCRATIC POLITIES}

Political accountability identifies a relationship between citizens (subjects) as "principals" and political representatives and decision-makers as "agents". Politicians who make binding decisions over the rules of conduct and the allocation of scarce resources in a polity are responsive to principals when they deliver benefits such constituencies value. Politicians' responsiveness may be based on the ability of the subjects to hold them effectively accountable for their actions, i.e. replace them by competing politicians, when the original set of politicians fails to be responsive, provided that there is a minimal level of civil liberties, periodic elections, and a rule of law. If relations of democratic accountability succeed, we may say that a democratic polity builds effective "linkages" between citizens and politicians. 
Whether or not and how such accountability relations work in practice, however, is associated with a big question mark. What is it that politicians -or teams of politicians called "parties"-need to accomplish to make themselves appear responsive to citizens and build a working relationship of accountability and linkage? Simply to check whether or not politicians and parties are popular begs the question: What are politicians' and parties' achievements that make them more or less popular? What are the grounds on which citizens align behind politicians and parties?

For many decades, one answer the political science literature has given to this question emphasizes the role of expressive, emotional mechanisms constituting accountability and linkage between principals and agents. One of them is party identification, or an affective bond between a citizen and the individual politicians as well as the organization of her preferred party, often handed down through socialization from generation to generation within families. Another expressive mechanism is descriptive representation, or the preference for voters to support candidates who share ascriptive traits with their electorates that are difficult or impossible to alter (race, ethnicity, religion, language, gender, region/residence). A third expressive mechanism concerns the personal conduct of a politician that arouses special popular loyalty or enthusiasm, or what Max Weber called the personal charisma of a politician, net of whatever else the politician does to benefit her constituency.

Critics of the expressive voting literature have always pointed out that party identification, descriptive representation, and leadership charisma at least in part mask more instrumental, calculated grounds that bind principals to agents. Thus party identification may really amount to a "running tally" (Fiorina 1981) of what generations of politicians working within a partisan label have cumulatively achieved for their constituencies in terms of providing material benefits. Individual parties or coalitions of parties deploy "policy" and "partisan programs" with catalogues of club goods that appeal to an array of supporters and hopefully enable them to cobble together enough groups to capture the median voter and govern the country. Party identification, descriptive representation, and personal charisma, to a certain extent, are not purely emotional expressive bonds between citizens and politicians, but at least in part reveal citizens' instrumental considerations that politicians with certain traits will deliver policies that make their voters better off. As a consequence, in the political science literature on parties and party systems, as well as in the comparative political economy literature, a "responsible partisan model" of the democratic process has reigned supreme that focuses on instrumental policy-based principal-agent relations.

Others have pointed out that some of the goods politicians deliver in the instrumental model tend to have the character of valence goods all citizens want to enjoy, such as economic growth, rather than positional club goods advantaging some but often at the expense of others. More recently, research in macro-political processes in the United States has therefore combined a positional and a valence perspective by showing how citizens' evaluations of politicians and willingness to support them interweave considerations of politicians' partisan positions on divisive policies and their demonstrated or likely competence of conduct in office in delivering collective goods (Erikson et al. 2003). Particularly retrospective 
and prospective "economic voting" on the past record or future capacity of politicians to deliver collective goods are in the cross-hairs of investigations focused on valence competition.

What these two instrumental perspectives, as well as the expressive-emotional conceptualizations of democratic principal-agent linkage, leave out, however, is the possibility of political accountability through a direct exchange of a citizen's support of a party (through the vote, but also the contribution of money or labor) for targeted personal material advantages and honors tailored to specific individual supporters and small groups of supporters. It is not public goods or large-scale club goods that are the currency of instrumental principal-agent relations, but "private" goods and localized club goods accruing to families and small neighborhoods. Here politicians and voters construct a contingent and often ongoing, iterative relationship where one side delivers its benefit only as long as the other side reciprocates. This "clientelistic" mode of political accountability and competition obviously raises difficult challenges of monitoring and enforcement, particularly in an environment in which democratic institutions uphold the formal secrecy of the ballot. ${ }^{2}$

Figure 1 summarizes the typology of expressive and instrumental linkage types we have distinguished in the preceding paragraphs. The field of comparative politics has produced a sizeable literature that throws light on patterns of positional policy competition, accountability and resulting alignments between voters and politicians, as well as the change ("realignment") or deterioration ("dealignment") of such accountability relations. In a similar vein, there is a detailed literature on valence competition, at least with regard to its economic retrospective and prospective voting aspect where scholarship has reached a certain theoretical and empirical maturity impressively demonstrated by Duch and Stevenson's (2008) recent comparative work. At the same time, there is no comparable comparative treatment of clientelistic politics, either in theoretical or in empirical terms, let alone a treatment of the relationship between clientelistic exchange and positional as well as valence variants of policy competition.

Both in the 1950s and 1960s, and then again starting in the 1990s, scholars have produced a torrent of country-level case studies or subnational comparative studies of clientelistic party competition. In both eras, the upswings of attention to clientelism coincide with the extension of democratic politics beyond the boundaries of Western affluent postindustrial democracies. But even in this "core" region clientelism was never completely absent and has drawn renewed attention, because its partial demise in countries where it was well entrenched triggered turmoil in a number of party systems in recent decades(Kitschelt 2007a). The literature on clientelism has not remained without progress. On the one hand, several scholars have made useful efforts to integrate clientelistic modes of accountability into formal models of party competition (Stokes 2005; Magaloni, Diaz-Cayeros et al. 2007; Medina and Stokes 2007; Nichter 2008). On the other hand, beyond a range of highly instructive ethnographic case studies, scholars have produced some quantitative empirical 
Figure 1: Modes of Political Linkage in Democracies

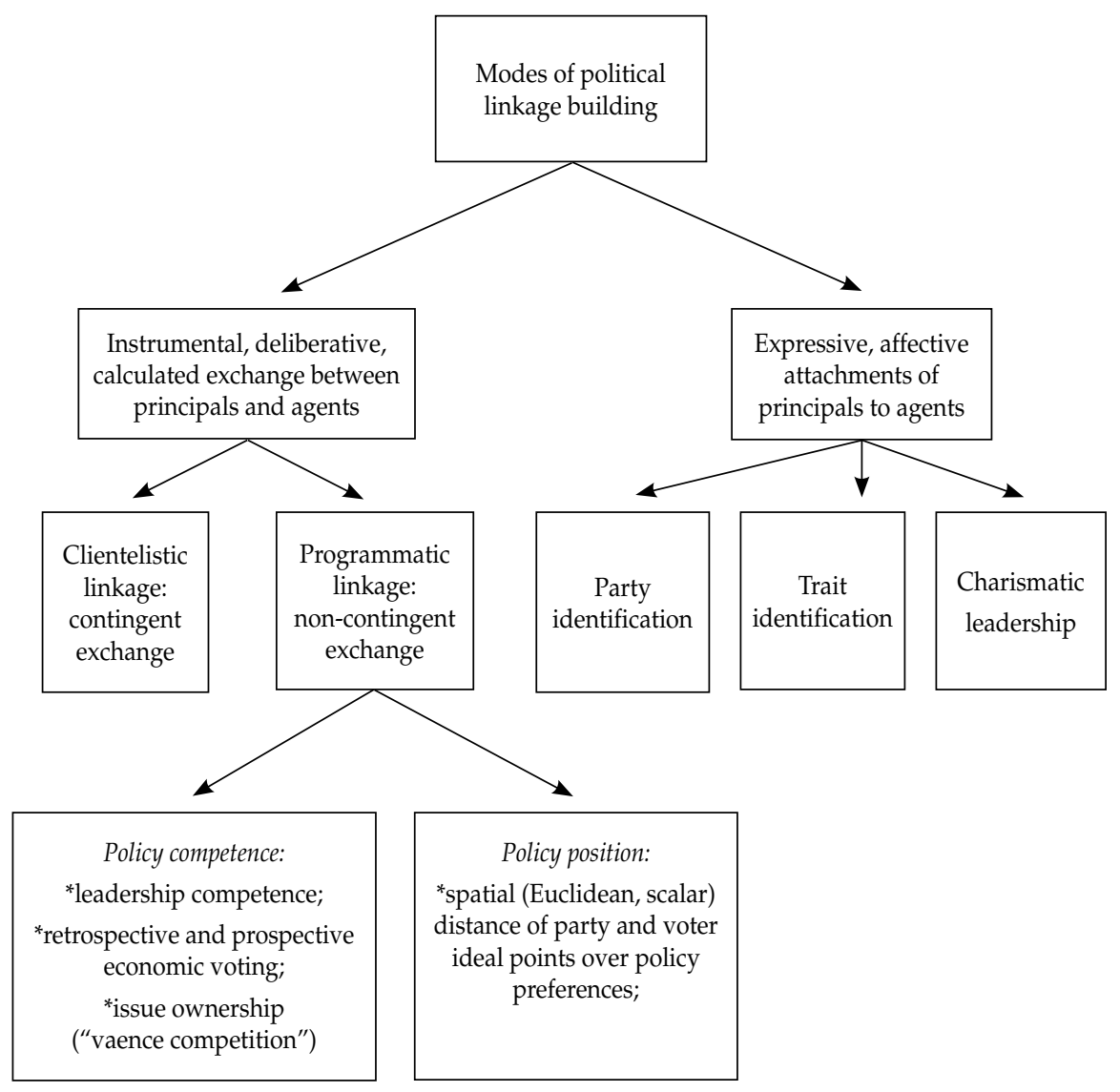

studies that have explored clientelism through public opinion surveys or subnational structural data within countries (Calvo and Murillo 2004; Stokes 2005).

Because of the absence of a concerted effort to measure clientelism by constructing a cross-national data set, however, there has been relatively little effort to probe into the systemic conditions and consequences of the profiles of political accountability relations (positional, valence and/or clientelistic?) that characterize party competition in different polities and over time. Piattoni (2001) has produced one instructive extension and test of Shefter's (1977) work to a broader set of European democracies(Piattoni 2001). Where quantitative estimates of clientelism have been needed for cross-national comparative research, papers rely on presumable indirect tracers of the presence of clientelism in a polity, such as the size of the civil service as a proportion of total employment and/or the size of public investment/construction budgets (Keefer 2006).

In light of this status of the research frontier, our current project on democratic accountability mechanism constitutes an effort to provide a comparative party-level and polity-level 
data-set on profiles of democratic linkage mechanisms around the globe. Before we sketch the construction of the research instrument, let us indicate a set of questions that we plan to address with this instrument. ${ }^{3}$ The focal theme of interest is democratic accountability relations or linkage mechanisms, with a particular emphasis on the incidence of "clientelism". In order to account for clientelistic principal-agent relations, however, it will be critical to analyze politicians' and voters' choices of and coordination around "portfolios" or "profiles" of accountability relations, i.e. N-tuples with scores on clientelism, valence, and policy as "instrumental" aspects of accountability and scores on candidate personality, party identification, and descriptive representation as "expressive" aspects of accountability.

Of course, a research program explaining the entire range of linkage profiles will be too hard to manage from the very start. Our strategy will be to focus on individual linkage mechanisms first and treat values on others as exogenously given. We may then complicate the picture and examine the interactive choice of pairs or triplets of linkage mechanisms. A rewarding candidate in this regard is the often intuitive, tacit, and theoretically unquestioned implicit proposition that there is a simple one-to-one trade-off between pairs/triplets of accountability mechanisms: Politicians and voters coordinate either around policy (positional) or valence issues or around clientelism/ targeted exchange or around charismatic personalistic appeals. As a research question we need to leave open the possibility that politicians are able to combine different accountability mechanisms in identifiable and theoretically explicable profiles, depending on the utilities different voter groups assign to different political "services" and the strategies of competing politicians to satisfy such services as well. In other words, politicians can develop complex linkage strategies in their quest for votes, office, and executive power.

Looking upstream in the causal chain, we would like to explain how politicians and voters coordinate around different individual principal-agent-accountability mechanisms and more complex profiles in which clientelism may play a more or a less prominent role. The most prominent and widely embraced, but never systematically tested hypothesis is the development hypothesis according to which progressive economic development shifts partisan competition from a profile with strong clientelistic elements to a profile with strong policy linkage, with uncertain implications for charismatic appeals. Beyond the development hypothesis, an institutionalist hypothesis has widely resonated in the field. It maintains that electoral ballot structures, formula, and district size that interact to highlight competition among individual politicians more so than among teams of partisan candidates also encourage accountability profiles strong on clientelism and charisma and weak on policy.

Then there are various competitiveness hypotheses according to which the profile of linkages as well as the effort made by politicians to build linkages depend on the "competitiveness"

3 For a more detailed account of theories of democratic linkage mechanisms, with a particular emphasis on clientelism, see Kitschelt (2000) and Kitschelt and Wilkinson (2007b). 
of the inter-party configuration. A party system is generally considered more competitive where small changes in parties' vote support make big differences in their respective bargaining leverage and control over executive office and its spoils. It is quite difficult to conceptualize this notion of competitiveness at a theoretical and operational level (Kitschelt 2007b).

A further hypothesis is the civil service hypothesis first put forth by Shefter according to which the preexistence of a bureaucratic-absolutist state undercuts politicians' opportunities to incorporate clientelism in their linkage portfolio, once suffrage becomes universal and state executives democratically accountable (Shefter 1977). More generally, one could frame a political economy hypothesis that relates the prominence of policy and clientelistic concerns in democratic partisan politics to the depth of government regulation or ownership in manufacturing and service establishments of modern economies. Finally, there is the ethnic pluralism hypothesis, or better: "family" of hypotheses, according to which ethnic pluralization promotes clientelism, as it simplifies monitoring of voting behavior and channeling of benefits. All of these hypotheses, of course, require detailed theoretical refinement to arrive at analytically tractable predictions.

Looking downstream in the causal chain, individual linkage mechanisms and complex profiles of democratic linkage may leave causal imprints on a variety of features within and beyond the polity. As a most proximate effect, linkage mechanisms may shape the process of democratic politics, such as party system attributes themselves (fragmentation, polarization, volatility) or the nature and longevity of government executives. As a more distant causal effect, profiles of linkage mechanisms, and particularly the prominence of clientelistic exchange, may also affect the distribution of life chances in society, and especially income distribution and economic growth, as well as the protection and provision of collective goods (such as environmental protection). Studies of democratic linkage mechanisms interface here with comparative political economy. Thus much recent research on clientelistic linkage is situated at the intersection with comparative political economy and addresses the question of how different profiles of democratic accountability mechanisms affect (and are affected by) the market liberalization of statist political economies.

Finally, and partly as a result of the impact of democratic linkage mechanisms on political process features and political economic outputs and outcomes, profiles of democratic accountability may affect systemic trust in democracy and support for democracy as a political regime form. It is certainly a reflex among intellectuals to consider clientelism as a deficient form of democratic accountability that generates cynicism and disaffection about democratic politics for a variety of reasons, the most important may be that it undermines the fiction of formal equality before the law by treating citizens not as equals, but contingent upon their vote or campaign contributions to the electoral winners. Yet viewed through the lens of many electoral constituencies it may not be entirely self-evident that the presence of clientelistic accountability undermines support for democracy. Quite to the contrary, many citizens may see this mode of linkage as their primary avenue to hold elected politicians responsible. 


\section{RESEARCHING DEMOCRATIC ACCOUNTABILITY PROFILES}

Having motivated the relevance of the attempt to construct a cross-national data-set on democratic linkage mechanisms in general and clientelistic accountability in particular, let us now turn to options to measure such political processes empirically and to sketch the research strategy chosen in this project. With regard to policy both in terms of programmatic appeals and valence/retrospective \& prospective economic voting, at least, we have a variety of established methodologies delivering micro- and macro-data we will not review here. ${ }^{4}$ It would also take another venue to review and brainstorm about comparative data sets concerning expressive accountability mechanisms, particularly party identification and descriptive representation where some data are available on gender representation, but little comparatively usable data on ethnocultural representation, although Kanchan Chandra's forthcoming dataset on ethnocultural representation will be helpful in this regard (cf. Chandra and Wilkinson 2008).

The bulk of research on clientelism is ethnographic field research in localized case studies. This work is essential and highly instructive, particular for any effort to determine how contingent exchanges can be consummated under conditions of universal suffrage and at least a modicum of voter privacy at the ballot station. A second avenue is survey research in which voters are asked to indicate the extent and nature of contacts they had with legislators or candidates for legislative office and to describe any benefits they have derived from such contacts. Both anthropological and survey research are useful, but hitherto have provided data only about individual countries or subnational jurisdictions.

A third avenue to pursue clientelistic exchange is through indirect macro-quantitative indicators. This work postulates that clientelism coincides with corruption, bad governance (rule of law, due process), or over-sized capital investment budgets and civil service staffing arrangements so that indicators of such practices can be deployed as tracers of clientelistic arrangements. We believe there may be some plausibility to this presumption, but it would be informative to explore the extent to which this is or is not true and isolate the incidence of transactional political practices from such broader phenomena as corruption and public sector patronage. These general indicators may be too coarse to assist research focused on illuminating politicians' and voters' linkage building strategies in democratic competitive polities where clientelism sometimes may involve very little corruption (or practices labeled as corruption), but constitute widely accepted, legally uncontestable ways of political conduct expected by substantial proportions of the electorate.

For these reasons, and in order to combine information on several principal agent linkage mechanisms, especially clientelistic exchange, programmatic policy appeal and emphasis on charismatic leadership personality, in a single investigation of democratic accountability under one organizational roof, the current project on which we report has settled for a cross-national expert survey. In each country, panels of 10-20 scholars whose research and

4 See especially the wonderful special issue of Electoral Studies on the validity of expert, manifesto, and survey data to determine the issue appeals of political parties (Volume 26, 2007, N ${ }^{\circ}$ ) as well as Gabel and Huber (2000) and Laver, Benoit and Garry (2003). 
teaching concern parties' electoral campaigns and voter appeals and additional very small panels of 3-5 journalists who cover elections for national newspapers are asked to score relevant parties in their respective countries on a variety of traits and practices.

We realize that an expert survey of this nature is a poor second-best to a more direct fieldbased, but systematically comparative approach to the study of linkage mechanisms generally and clientelistic exchange specifically in which researchers collect data in each country for a period of two months minimum, visit a number of sites characterized by theoretically important variance in local conditions (urbanization/development; party system competitiveness; urban/rural and or ethnic divisions), and score check lists of attributes in each place based on a sample of local informants, including scholars, journalists and the politicians themselves. But for 90 countries this research strategy would require a minimum financial input of $\$ 2.0$ million (assuming a modest $\$ 15,000-18,000$ per country for travel and salary, plus research administration), or about $8+$ times the resources actually available for our current undertaking. ${ }^{5}$

The survey consists of five modules each of which started out as batteries of questions that were several times as long, but then paired back to make survey completion manageable within 60-90 minutes (depending on the number of parties scored) and within a horizon of knowledge that scholars and journalists might be moderately confident in the accuracy of the judgments they are passing. In almost all questions the unit of judgment (or levels of observation) is party $\mathrm{j}$ in country $\mathrm{k}$, with one score requested for each party. In a few questions, respondents can indicate more than one response category per party. In a few other instances, questions ask respondents to pass aggregating judgments about partisan practices in general in their countries (level of observation: polity). Table 1 presents the breakdown of questions in the five modules, levels of observation, and the scoring metrics of the variables.

The first survey module concerns party organization $(A)$ and internal decision making. We included it for a variety of theoretical reasons one of which is that clientelistic or programmatic party competition may work only if politicians have resolved problems of collective action sufficiently to mobilize and target resources or advertise and act on policy appeals.

The second module in our survey concerns practices of targeted exchange (B). It is worth reporting that this section of the survey is prefaced by a "quasi-vignette" to influence respondents anchor points in interpreting the scales. It gives some instructions on how to interpret the endpoints of scales rating the bountifulness of targeted transfers, particularly the high extreme of such scales. The first five items in this module then ask respondents to assess how much efforts parties make to provide different kinds of targeted goods and services to voters (B.1 - B.5).

5 The actual figure of about \$250,000+ includes funds from the World Bank, Kitschelt's personal research account at Duke University, and research funds from the Chilean Science Foundation made available to the associated project that conducted the Latin American research and directed by Juan Pablo Luna and David Altman, Catholic University of Chile. 
Table 1: The Expert Survey Instrument

\begin{tabular}{|c|c|c|c|c|}
\hline Survey Section & & Question Content & $\begin{array}{l}\text { Level of } \\
\text { observation }\end{array}$ & $\begin{array}{c}\text { Scoring range } \\
\text { (measurement } \\
\text { level) }\end{array}$ \\
\hline \multirow{12}{*}{$\begin{array}{l}\text { Part A } \\
\text { organizational } \\
\text { capabilities and } \\
\text { power structure }\end{array}$} & A.1. & $\begin{array}{l}\text { extensiveness of party organization: local district } \\
\text { offices? ( } 1 \text { = extensive) }\end{array}$ & party & $1-4$, ordinal \\
\hline & A. 2 . & $\begin{array}{l}\text { party organized social/community presence, } \\
\text { ancillary groups (youth groups, women, } \\
\text { cooperatives, athletic clubs...) (1 = yes) }\end{array}$ & party & $0 / 1$, ordinal \\
\hline & A.3. & $\begin{array}{l}\text { party reliance on local intermediaries (notables, } \\
\text { religious leaders, neighborhood leaders) } \\
\text { (1 = extensive) }\end{array}$ & party & $1-3$, ordinal \\
\hline & A.4. & $\begin{array}{l}\text { reliance on party members in nomination of } \\
\text { legislators: Centralization of control? } \\
\text { (1= members involved in most districts) }\end{array}$ & party & $1-3$, ordinal \\
\hline & A.5. & $\begin{array}{l}\text { legislative candidate nomination: power } \\
\text { distribution? (1 = national party leaders) }\end{array}$ & party & $1-4 ;$ nominal $^{*}$ \\
\hline & A.6. & $\begin{array}{l}\text { control over national party electoral strategy? } \\
\text { (1 = national party leaders) }\end{array}$ & party & $1-4 ;$ nominal $^{*}$ \\
\hline & A.7. & $\begin{array}{l}\text { existence of stable organized factions within } \\
\text { party? }(1=\text { yes })\end{array}$ & party & 0/1 nominal \\
\hline & A.8. & $\begin{array}{l}\text { 1-6. party-group linkages: business/professional } \\
\text { associations, etc. ( } 1=\text { yes })\end{array}$ & party & 0/1 nominal \\
\hline & A.9. & $\begin{array}{l}\text { relevance of public subsidies for party funding? } \\
(1=\text { most revenue })\end{array}$ & party & $1-3$, ordinal \\
\hline & A.10. & $\begin{array}{l}\text { private funding - compliance with financial } \\
\text { regulation? }(1=\text { most in compliance })\end{array}$ & party & $1-4 ;$ nominal $^{*}$ \\
\hline & A.11. & $\begin{array}{l}\text { public funding - compliance with national } \\
\text { regulation? }(1=\text { most in compliance })\end{array}$ & party & $1-4 ;$ nominal $^{*}$ \\
\hline & A.12. & $\begin{array}{l}\text { self-assessment: How confident in one's own } \\
\text { assessment of A1-11? }(1=\text { low })\end{array}$ & party & $1-4$ ordinal \\
\hline \multirow{7}{*}{$\begin{array}{l}\text { Part B } \\
\text { Benefits targeted } \\
\text { to individual } \\
\text { citizens and } \\
\text { small groups }\end{array}$} & B.1. & effort to give/promise to give consumer goods & party & 1-4 ordinal \\
\hline & B.2. & $\begin{array}{l}(1=\text { negligible } / \text { not }) \\
\text { effort to give / promise voters preferential access } \\
\text { to social policy entitlements }\end{array}$ & party & 1-4 ordinal \\
\hline & B.3. & $\begin{array}{l}\text { effort to give/promise voters employment in } \\
\text { public or regulated sector }\end{array}$ & party & $1-4$ ordinal \\
\hline & B.4. & $\begin{array}{l}\text { effort to give/promise voters preferential access to } \\
\text { government contracts or procurement opportunities } \\
\text { (1= negligible/not) }\end{array}$ & party & $1-4$ ordinal \\
\hline & B.5. & $\begin{array}{l}\text { effort to give/promise voters influence over } \\
\text { regulatory proceedings ( } 1=\text { negl.) }\end{array}$ & party & 1-4 ordinal \\
\hline & B.6. & $\begin{array}{l}\text { overall effort to induce voters with preferential } \\
\text { benefits }(1=\text { negligible } / \text { not })\end{array}$ & country & $1-5$ ordinal \\
\hline & B.7. & $\begin{array}{l}\text { change in effort over last } 10 \text { years; }(\text { much less }=1 \text {; } \\
\text { much more }=5 \text { ) }\end{array}$ & Country & $1-5$ ordinal \\
\hline
\end{tabular}


(continuation tabla 1)

\begin{tabular}{|c|c|c|c|c|}
\hline Survey Section & & Question Content & $\begin{array}{l}\text { Level of } \\
\text { observation }\end{array}$ & $\begin{array}{l}\text { Scoring range } \\
\text { (measurement } \\
\text { level) }\end{array}$ \\
\hline \multirow[t]{3}{*}{ Part B } & B.8. & group member targeting: rural, urban, ethnic & party & $1 / 0,3$ dummies \\
\hline & B.9. & $\begin{array}{l}\text { group member targeting: poor-middle-wealthy } \\
(1=\text { poor })\end{array}$ & party & $1-3$ ordinal \\
\hline & B.10. & $\begin{array}{l}\text { parties' transmission belts to deliver targeted goods: } \\
\text { unions, business associations; religious groups; } \\
\text { ethnic groups; urban or rural; women; }\end{array}$ & party & $0 / 1,6$ dummies \\
\hline \multirow{9}{*}{$\begin{array}{l}\text { Part C } \\
\text { Monitoring } \\
+ \text { enforcing }\end{array}$} & B.11. & $\begin{array}{l}\text { effectiveness of targeted benefits for political } \\
\text { parties } 1=\text { not at all }\end{array}$ & party & $1-4$ ordinal \\
\hline & B.12. & $\begin{array}{l}\text { targeting party loyalists }(=1) \text {, strategic voters }(=2) \\
\text { or both }(=3)\end{array}$ & party & $1-3$, nominal $^{*}$ \\
\hline & B.13. & $\begin{array}{l}\text { self-assessment: How confident in one's own } \\
\text { assessment of B1-12? }\end{array}$ & party & $1-4$ ordinal \\
\hline & C.1. & monitoring of voters ... successful? (all parties) & party & 1-4 ordinal \\
\hline & C.2. & $\begin{array}{l}\text { group allies in determining the candidate's vote? } \\
\text { (multiple } 0 / 1 \text { dummies) }\end{array}$ & Party & $0 / 1,6$ dummies \\
\hline & C.3. & open-ended: describe practices of monitoring & party & $\mathrm{n} / \mathrm{a}$ \\
\hline & C.4. & Sanctions for non-delivery of the vote & party & $0 / 1$ dummy \\
\hline & C.5. & $\begin{array}{l}\text { change in politicians' capacity to figure out voters } \\
(4=\text { very strong) }\end{array}$ & Country & $1-4$ ordinal \\
\hline & C.6. & $\begin{array}{l}\text { self-assessment - How confident in one's own } \\
\text { assessment of C1-5? }\end{array}$ & party & 1-4 ordinal \\
\hline \multirow{9}{*}{$\begin{array}{l}\text { Part D } \\
\text { Policy } \\
\text { Positions }\end{array}$} & D.1. & $\begin{array}{l}\text { parties' policy positions - spending on the } \\
\text { disadvantaged (against }=10)\end{array}$ & party & $1-10$ ordinal \\
\hline & D.2. & $\begin{array}{l}\text { parties' policy positions - state role in governing } \\
\text { the economy (minimal = 10) }\end{array}$ & party & $1-10$ ordinal \\
\hline & D.3. & $\begin{array}{l}\text { parties' policy positions - social expenditure } \\
\text { (against = 10) }\end{array}$ & party & $1-10$ ordinal \\
\hline & D.4. & $\begin{array}{l}\text { parties' policy positions - defense of national } \\
\text { identity and culture (high }=10)\end{array}$ & party & $1-10$ ordinal \\
\hline & D.5. & $\begin{array}{l}\text { parties' policy positions - compliance with } \\
\text { traditional moral authorities and values } \\
(\text { high }=10)\end{array}$ & party & $1-10$ ordinal \\
\hline & D.7. & $\begin{array}{l}\text { - D.N. parties' policy positions - custom questions } \\
\text { tailored to individual countries }\end{array}$ & (party) & $1-10$ ordinal \\
\hline & & $\begin{array}{l}\text { D.W. parties' policy positions - left-right scale } \\
\text { placements of parties }(10=\text { right })\end{array}$ & party & $1-10$ ordinal \\
\hline & & $\begin{array}{l}\text { D.X. self-assessment- How confident in one's own } \\
\text { assessment of D-1 - D-W }\end{array}$ & party & $1-4$ ordinal \\
\hline & & $\begin{array}{l}\text { D.Y. sympathy } / \text { closeness to a party } \\
\text { (same views }=1 ; \text { different views }=10 \text { ) }\end{array}$ & party & $1-10$ ordinal \\
\hline
\end{tabular}

${ }^{*}$ some of the options are ordinally scaled, but at least one option cannot be placed in the ordinal scale. 
(continuation tabla 1)

\begin{tabular}{|c|c|c|c|c|}
\hline Survey Section & & Question Content & $\begin{array}{l}\text { Level of } \\
\text { observation }\end{array}$ & $\begin{array}{l}\text { Scoring range } \\
\text { (measurement } \\
\text { level) }\end{array}$ \\
\hline \multirow{5}{*}{$\begin{array}{l}\text { Part E } \\
\text { Summary } \\
\text { judgments }\end{array}$} & E.1. & parties' mobilizational effort ...featuring a & party & 1-4 ordinal \\
\hline & E.2. & $\begin{array}{l}\text { leader's charismatic personality? } \\
\text { parties' mobilizational effort ...attractiveness of } \\
\text { the party's policy positions? }\end{array}$ & party & 1-4 ordinal \\
\hline & E.3. & $\begin{array}{l}\text { parties' mobilizational effort...capacity to deliver } \\
\text { targeted material benefits }\end{array}$ & party & 1-4 ordinal \\
\hline & E.4. & $\begin{array}{l}\text { parties' mobilizational effort...invoke loyalty, } \\
\text { party history, party ID }\end{array}$ & party & 1-4 ordinal \\
\hline & E.5. & $\begin{array}{l}\text { parties' mobilizational effort...parties' claim to } \\
\text { competence to govern }\end{array}$ & party & 1-4 ordinal \\
\hline
\end{tabular}

The short module $C$ on monitoring and enforcing compliance with contingent exchange is probably the most difficult to frame in any rigid closed-format survey template. The survey preparatory group went through many iterations of draft questions and pilot tests of alternative formulations to get at the underlying theoretical issue. It is difficult to formulate because (1) monitoring and sanctioning practices tend to be highly localized, tacit, concealed, and even clandestine and (2) there is a great diversity of practices that vary with institutional settings and organizational partisan capabilities. Hence it is all but impossible to formulate a one-size-fits-all battery of questions. As a last resort, we opted for a general question that asks how successful parties are, provided they check at all how specific individuals or small groups of voters opted at the ballot station.

Module $D$ is the most conventional one in the survey, as it requests scholars and journalists to score each party's (spatial) positions on 1-10 policy issue scales. We provide five "generic" scales for all surveys (D.1. through D.5). Three of them tap aspects of economic-distributive issues and two deal with socio-cultural topics of defining insiders and outsiders and of collective regulatory prerogatives over individual choice. In most countries, we have also added country-specific policy issues (D.7 and up), typically by homing in on issues that are known or likely to generate inter-party divisions. These additional questions help prevent an underreporting of programmatic competition simply because the generic policy questions D.1 through D.5 may not be the correct questions on which to score partisan policy divides in a country. There may be idiosyncratic issues that are relevant only in one or several countries, but structure the spectrum of partisan alternatives programmatically.

Each question of the final Module E asks respondents to give one general score for each party in their country for five of the six linkage mechanisms depicted in figure 1, charisma (E.1), policy (E.2), targeted benefits (E.3), activities to invigorate emotional party identification (E.4) and valence/competence voting (E.5). We only left out descriptive 
voting, as results are difficult to compare, given countries very different ethnocultural compositions, and as we hope to employ other objective indicators for this potential linkage mechanism.

Let us briefly sketch the implementation of the project with this survey instrument. In each country, with the exception of 15 South American countries ${ }^{6}$, we identified a "country anchor" who volunteered to contact prospective survey respondents and solicit their participation in the project, often with the help of a research assistant. Country anchors also decided on additional policy questions tailored to the domestic political discourse in part D of the survey and, where necessary, modified the language of the survey in part A, where questions are asked about institutional attributes of parties in a generic terminology that must be respecified for local respondents to be intelligible.

In addition, anchors also selected survey participants among local scholars with specific knowledge and a track record of research, as well as between three to five journalists who covered political parties, campaigns and elections. Table 2 contains the full list of countries where the survey was implemented.

Table 2: Countries Included in the Survey

\begin{tabular}{|c|c|c|}
\hline Region & $\begin{array}{l}\text { Data collection } \\
\text { completed }\end{array}$ & $\begin{array}{l}\text { Data collection } \\
\text { planned or active }\end{array}$ \\
\hline $\begin{array}{l}\text { Western Europe } \\
+ \text { Settler } \\
\text { democracies }\end{array}$ & $\begin{array}{l}\text { Australia, Austria, Belgium, Canada, Denmark, } \\
\text { Finland, France, Germany, Greece, Ireland, Italy, } \\
\text { Netherlands, New Zealand, Norway, Portugal, Spain, } \\
\text { Sweden, Switzerland, United Kingdom, United States } \\
\text { (20) }\end{array}$ & \\
\hline $\begin{array}{l}\text { Post-communist } \\
\text { region }\end{array}$ & $\begin{array}{l}\text { Albania, Bulgaria, Croatia, Czech Republic, Estonia, } \\
\text { Georgia, Hungary, Latvia, Lithuania, Macedonia, } \\
\text { Moldova, Mongolia, Poland, Romania, Russia, Serbia, } \\
\text { Slovakia, Slovenia, Ukraine (19) }\end{array}$ & \\
\hline Latin america & $\begin{array}{l}\text { Argentina, Bolivia, Brazil , Chile, Colombia, Costa } \\
\text { Rica, Dominican Republic, Ecuador, El Salvador, } \\
\text { Guatemala, Honduras, Jamaica, Mexico, Nicaragua, } \\
\text { Panama, Paraguay, Peru, Uruguay, Venezuela (19) }\end{array}$ & Trinidad \& Tobago \\
\hline $\begin{array}{l}\text { Sub-Saharan } \\
\text { Africa }\end{array}$ & $\begin{array}{l}\text { Angola, Benin, Botswana, Ghana, Kenya, Mali, } \\
\text { Mozambique, Namibia, Niger, Nigeria, Senegal, South } \\
\text { Africa, Tanzania, Zambia (14) }\end{array}$ & Mauritius \\
\hline $\begin{array}{l}\text { Asia and middle } \\
\text { east }\end{array}$ & $\begin{array}{l}\text { Bangladesh, Egypt, India, Indonesia, Israel, Japan, } \\
\text { Malaysia, Morocco, Pakistan, Philippines, South Korea, } \\
\text { Taiwan, Thailand, Turkey (14) }\end{array}$ & Lebanon \\
\hline Coverage & 86 & 3 \\
\hline
\end{tabular}

6 In Latin America, the survey was implemented by David Altman and Juan Pablo Luna from the Catholic University of Santiago de Chile. 


\section{METHODOLOGICAL CHALLENGES}

The data collected in this project are vulnerable primarily to four major problems we detail below. We expect that these methodological problems will create a fog of measurement error, but we hope it is going to be a fog through which relevant features of politics can still be glimpsed and discerned better than with other hitherto deployed instruments. Ultimately, only the use of multiple data strategies and cross-triangulation of descriptive generalizations obtained by different methods will generate robust knowledge about the phenomena we wish to study.

At this point, we would be satisfied if the current dataset were to enable us to (re)produce what one might call the ordinary "collective wisdom" of the scholarly profession-or maybe only the "grounded prejudices" of that profession?-about the variance of attributes characterizing democratic accountability in party competition across a wide range of countries. The advantage of our dataset would still be that it delivers this common wisdom or prejudice in an explicit, systematic, comprehensive, and thematically inclusive way, while most judgments about attributes of democratic partisan politics, particularly in small-N comparisons across countries, tend to be ad-hoc, incomplete, and narrow in the property domain covered.

\section{a. Sources of Measurement Error and Bias}

A first major problem in expert surveys has to do with the limited expertise of the experts. Many questions concerning democratic accountability mechanisms would have to draw on a detail of knowledge even experts can obtain only through thorough field research. Even the questions included in our survey may tax the knowledge of scholars who generally monitor parties and elections and research performed in this field in their own country. Lack of knowledge is thus a powerful generator of measurement error. Moreover, this measurement error may vary across polities, as more is known about the operation in some countries rather than others.

A second major problem has to do with the aggregation of data to a high level. In this survey, we are essentially dealing with two to three levels of aggregation, and a fourth level can and may well need to be constructed:

(L-1) party level: assessing individual attributes; (e.g., questions B.1, B.2 ....);

(L-2) party level: assessing a general pattern of attributes by party (e.g. questions B.8, B.9.... C.1, E.1,

E.2 (... see table 1);

(L-3) country level: assessing a general pattern of attributes across all parties in a country (e.g., questions B.6, B.7, C.5);

(L-4) country level general patterns of attributes, in which the party scores are weighted according to 
(i) party size in the electorate (or legislature) and

(ii) current and/or cumulative government status over some years;

Even questions at the greatest level of disaggregation in the dataset (L-1: individual party, individual attribute) assume that politicians' practices are either uniform across all locales of a country or that a simple aggregation process from localities and regions to the national level can give a summary assessment for the country as a whole, and in similar ways across a set of countries. All that can be hoped for is that the mean (aggregate) values expert survey respondents generate on an attribute for each party/country with a great deal of glossing over subnational variance still generates cross-nationally diverse "central tendencies" that track theoretically intelligible and relevant phenomena.

The third problem of cross-national data sets is that of anchor points or experts' perception of the variable scales. Based on their localized experience, and a limited range of experience beyond, experts in country A interpret the same kind of behavior differently on the scale than in country B. The cardinal scores of parties/countries on an attribute are not comparable across countries. The same behavior that appears to experts as indicating a "high" value in one country appears to be a rather "lower" value to experts in another country.

Gary King and colleagues (King, Murray et al. 2004; King and Wand 2007) proposed to reduce anchor point heterogeneity by giving survey respondents in different settings identically worded hypothetical questions and fact patterns. Their responses to the actual questions in the domain of the survey can then be expressed in terms of a difference to the scores experts provide to the common hypothetical fact pattern questions. While this proposal has a great deal of merit in theory, in most empirical real-world situations resource constraints (respondents' time, cost of survey production etc.) are so tight that researchers simply cannot afford a proliferation of vignettes respondents would have to assess in addition to the "real" questions. Piling on vignettes, therefore, would have made the expert survey quite unmanageable. For this reason, we opted for a single quasivignette in the preface to part B of the survey.

The fourth problem with expert data is bias, particularly given the small number of responses. Experts may want to project a specific image of a country or a party. Bias would both impair within-country comparison across parties as well as cross-country comparison. Clearcut ideological bias may be picked up in our survey by question D-Y about respondents' sympathies. Based on past experience with expert surveys, and even expert judgments of parties made by partisan politicians themselves, bias is rarely a problem in assessing parties' policy positions. At the margin, it may come in where a policy issue is clearly a valence issue with a very lop-sided distribution of preferences in the electorate.

A more serious problem might occur with regards to clientelistic practices. Intellectuals and upper-middle class citizens, tend to be most disaffected by and opposed to clientelism. It may well be, then, that respondents attribute to parties they generally dislike also a greater propensity to engage in clientelistic practices than respondents who are more sympathetic to such parties. Again, we have some indirect checks of bias in our dataset, as we may be able to calculate the respondents' sympathy scores with parties and compare the results with their assessment of the parties on indicators of clientelism. Nevertheless, 
respondents' anti-clientelistic biases might distort the scored relations among parties within some country and deflate or inflate differences between countries, contingent upon the intensity of respondents' anti-clientelistic affect for which we cannot control.

\section{b. Checking Out the Data: Strategy of Analysis}

We performed a series of preliminary tests of the data. We mention three of them in passing and focus primarily on data and concept validation. Our first concern had to do with the presence (or absence) of suitable patterns of variance between parties and countries. Indeed, there is variance at all levels in all survey modules that calls for explanation.

We were secondly concerned with variables that exhibit very high frequencies of nonresponses. Lack of a judgment by an expert can be both "subjective" and objective, in our view. The former arises when the expert lacks information, while the latter might indicate that the parties in a particular country are unclear with regards to a particular attribute or practice. This comes in handy, for example, when we evaluate left-right ideology and find that where some experts are highly uncertain in their judgments (e.g., refuse to score a party) the response patterns of other experts indeed suggest highly diffuse and ideologically vague parties and party systems.

An initial impressionistic inspection of cross-national response patterns shows a tendency to elevated rates of "don't know" (DK) and "missing value" (MV) indications (taken together, say $>20 \%$ of response opportunities) for a diverse field of variables in around 10 countries, among them Brazil, Chile, Germany, Guatemala, Macedonia, Mexico, Norway, Switzerland, and Venezuela. Further analysis will have to reveal whether these $\mathrm{DK}+\mathrm{MV}$ responses are concentrated on particular small parties or an across-theboard phenomenon.

As a third step, one may generate univariate distributions of rough highly aggregate indicators of attributes, say average scores of all parties in a country, and then eyeball the plausibility of revealed cross-national variance in light of what case study and qualitative comparative research tells us about our countries. Of course, data at this very high level of aggregation are particularly vulnerable to anchor point dependence when we engage in cross-national comparison. Similarities and differences between countries may simply be a consequence of national experts interpreting the scales differently in each country, on average.

A fourth step in probing more deeply into data validity is to try to reduce the anchor point problem directly by examining within-country variance, where the context of judgment, and presumably the anchor points of experts, are approximately similar. We accomplish this by avoiding a comparison of raw party scores, but instead computing the deviation of all parties in a country from the mean for that country on a particular question. This can also be addressed by evaluating the relationship between the parties' left-right position and their position on questions such as economic redistributions. Coefficients of the relationship between the two categories are then comparable across countries. We encourage the use of such strategies when using any expert data set to contain the anchor point problems inherent in such research designs. 
Finally, we follow psychometric theories to determine critical validity test of variables, or "construct validity" of the indicators in the dataset. This is the most complex, demanding, and possibly also ambiguous test of the validity of a data set. The basic idea is that we can test whether a variable validly measures an unobserved theoretical concept ("construct") by measuring its covariance with other empirical indicators that are known to relate to that theoretical object. Objects that have the same score on the valid measure of a construct should also have a corresponding score on one's new measure of that very same construct and vice versa. These are examples of "convergent validity". At the same time, a measure of a different theoretical construct that should not be related to the theoretical construct one is trying to measure also should not be related to one's new measure of the last construct ("discriminant validity"). Moreover, if a known valid measure of a theoretical construct predicts a certain observable effect that is causally attributed to that construct, then the new measure should do so likewise.

In the framework of the democratic accountability project, clientelistic and programmatic modes of accountability that involve particular activities on the part of politicians and voters to constitute "linkages" are unmeasured theoretical concepts. In the spirit of testing construct validity within the data set, let us see whether we have different measures of the same underlying construct that should be related to each other.

With regard to clientelistic competition, accountability, and linkage, the dataset gathers information about the activity of parties in generating targeted benefits for electoral constituencies and monitoring the conduct of voters or even sanctioning those who do not come through with their side of the deal. Some of the relations among these variables may count as construct validity tests, but in some instances we are looking at genuinely controversial causal relations that may or may not pertain, regardless of whether our variables tap our underlying theoretical construct correctly.

There are various measures of clientelistic goods provision at different levels of aggregation in our expert survey and one measure each of monitoring and sanctioning at the level of the party as unit of observation. Without having analyzed relationships empirically, let us consider whether the relationship among these different measures is conceptual, and thus examination of the correlation among them speaks to the question of construct validity, or causal, and thus a problematic matter of theorizing.

In the data sections that follow, we perform simple examinations of different variables taken from the dataset to examine the construct validity of these indicators for both programmatic and clientelistic modes of competition. In addition to these simple indicators examining whether related concepts taken from the survey do indeed tend to go together, we can also examine the validity of our new indicators with those that are broadly accepted in scholarly research as related to a theoretical concept. While in psychological measurements the tremendous proliferation of studies over the past $60+$ years is likely to make it quite easy to generate external construct validation for almost any new scale produced by ongoing research, we are in a much less fortunate situation when it comes to the study of democratic principal-agent linkages, particularly once we go beyond programmatic linkages. 
For the latter, we can compare our empirical profiles with those obtained in other data sets pertaining to programmatic competition, particularly the studies by Laver and Hunt (1992), Benoit and Laver (2006), Rohrschneider and Whitefield (2009) and the several surveys undertaken by the team of Marks, Hooghe, Wilson, Ray, Edwards and other collaborators (for detailed references see Marks et al. 2007). Following the Electoral Studies 2007 special issue, we could also cross-validate our data set by examining the convergence of our expert studies with findings based on the Comparative Party Manifestoes (CMP) Data Set, although we have some serious doubts how far CMP can be pushed (cf. Rehm, 2008). One limitation of all these external tests of construct validity is that our dataset tends to be geographically much more inclusive than existing data sets of party competition that tend to be confined to the affluent OECD democracies, together with some of the postcommunist countries and maybe some Latin American countries.

When it comes to studies of clientelism, however, it appears to us that we are missing the tools of external construct validation. All the concepts that, on the surface, are plausibly correlated with our measures of clientelistic exchange actually may involve a more complex causal relationship with clientelism that needs to be theorized so as to understand both the coincidence and the divergence of predictions that follow when one rather than another empirical measure is used. What comes first to mind is a relationship between clientelism, corruption, and vote buying. Another "elective affinity" often mentioned in the literature is that between clientelism and "bad governance" or weak rule of law. In all these instances, such concepts may well exhibit an empirical correlation with clientelism, but it is probably a theoretical mechanism that drives it, not a conceptual-definitional identity relationship.

\section{A FIRST GLIMPSE AT DATA I: POLICY POSITIONS}

With these considerations in mind, let us take a first glimpse at the data. Typically we try to report only one number for each country in our 86 country dataset. The national level data we present are means of party level data weighted by average electoral support received by parties in the most recent two legislative elections, whether they are the means of the scores experts assign to parties on a particular attribute or the standard deviations of such scores.

For programmatic party competition, we have a set of anywhere between our five core policy issues (D.1 through D.5) and up to 10 additional national customized policy issues (particularly in Latin America) on which we are able to gauge the programmatic differentiation and internal cohesiveness of political parties. In this glimpse at data, however, we will confine ourselves to the purely formal semantics of "left" and "right" that in many countries taps policy differences, although it sometimes constitutes primarily a symbolic marker to distinguish different partisan labels. As is well known, left and right can be filled with different content, contingent upon historical circumstances. While the variation of this content is a fascinating object of explanation, we will confine ourselves here simply to a rough gauge of whether democratic partisan politics in a 
country appears to be more or less shaped by programmatic competition, no matter what is its content.

Following Downs' (1957) theory of information misers, as further developed by Hinich and Munger (1994), citizens and politicians coordinate around left-right signals, because they are shortcuts for a large, but undefined set of possible policies. Even without having to make an effort to collect information about parties actual policy positions, citizens can essentially infer where parties might stand on an issue, if they know the party's basic programmatic-ideological appeal, expressed in left-right placement terms. If that is true, experts should have less trouble placing political parties in the left-right space, where parties indeed have sharply articulated issue positions. Conversely, where parties make vague or diffuse appeals or no appeals at all, experts do not know how to place them and, if they place them, tend to disagree over where parties are located in the left-right space. Furthermore, it is likely that programmatic party systems are more polarized, for example in the sense that the variance of parties' mean positions in a programmatically competitive system is greater than in a party system with vague and non-programmatic parties. We derive three indicators from the surveys that measure the relative programmatic competitiveness of party systems. Where that competitiveness is higher,

1) expert surveys will exhibit fewer non-responses, "no clear position" or "don't know" answers to the left-right part placement question. This proportion is then weighted by electoral returns from the last election, so smaller parties will have a relatively smaller weight in the development of this measure.;

2) experts will be more unified in their judgment of each party's left-right position, i.e. the mean standard deviations of left-right placements will be smaller;

3) parties will exhibit more polarization in the eyes of the experts, i.e. the standard deviation between the mean party left-right scores will be greater than in a programmatically more diffuse system. Of course, polarization is not the same as programmatic competition. Indeed, cases of "centripetal competition", where parties compete for centrist positions in the ideological space exist (Sartori 1976). However, from a mathematical viewpoint, we should expect a relationship between diffuseness of expert opinions and the presence of centrist means for the parties (that is, as experts have more variance in how they score parties, the mean party score should tend toward the center).

Figure 2 shows a scattergram between the first two measures. As we can see, experts in West European countries, but also in Eastern Europe, opt much more rarely for missing responses/don't knows and are more unified in their judgments than in Latin America and Sub-Saharan Africa. Asia/Middle East is a small sample so far in our survey with highly diverse cases. In spite of the coarse and highly aggregate nature of the data presented here, the data may "make sense" from the vantage point of expectations based on comparative political party system research. With some exceptions, it is the more established, institutionalized party systems in advanced capitalist democracies and post-communist countries in the West European zone of influence, as well as a few of the East Asian countries that display the sharpest patterns of programmatic competition. Sub-Saharan Africa is at the other extreme with high rates of non-responses, while Latin 
Figure 2: Average Standard Deviation of Parties' Left-Right Location and Proportion of Experts Refusing Parties' Left-Right Placement

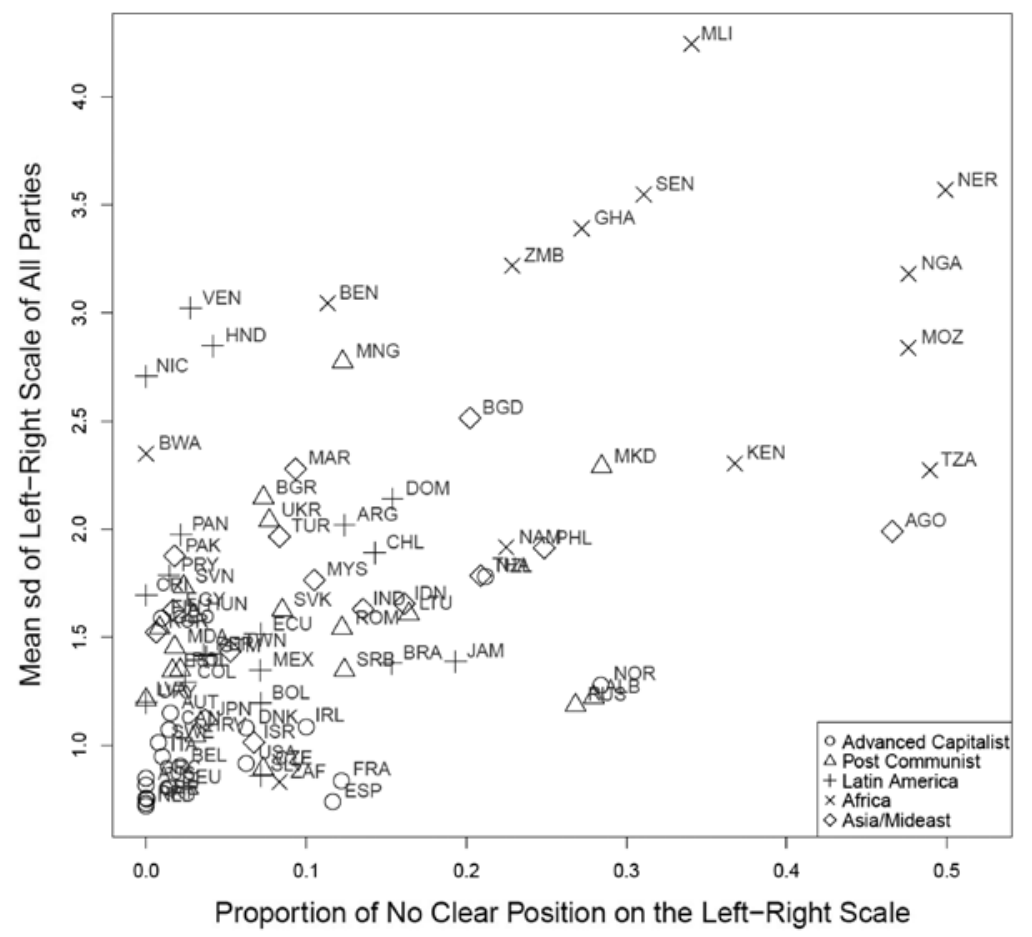

American countries are quite widely distributed across most of the range of scores, except very low missing response rates.

Figure 3, which roughly measures the polarization of parties in the country, also bears a remarkable similarity to Figure 2, albeit with the scale flipped. For the measure of polarization, we calculated the standard deviation for each country of the party means in that country. Again, the pattern is striking. Advanced capitalist countries tend to have the most polarized party systems, while party systems in Latin America, post-Communist Eastern Europe and Africa tend to have much less polarized systems. The argument relating polarization to the $\mathrm{DK} /$ non response and diffuseness of expert opinion measures utilized above is that more programmatic party systems will have clearer values that experts can attach to them. That is, they will be able to place different parties at different points in the ideological space.

In Section E of the survey, we invited experts to examine the extent to which politicians in their home countries utilized different linkage mechanisms with voters. These summary questions provide another programmatic measure that allows us to further investigate the validity of different programmatic competition indicators in our dataset. Figure 4 examines the correlation between question E. 2 in the survey (regarding the use of policy appeals by politicians) and the diffuseness of expert opinions on the left-right dimension. 
Figure 3: Left-Right Polarization

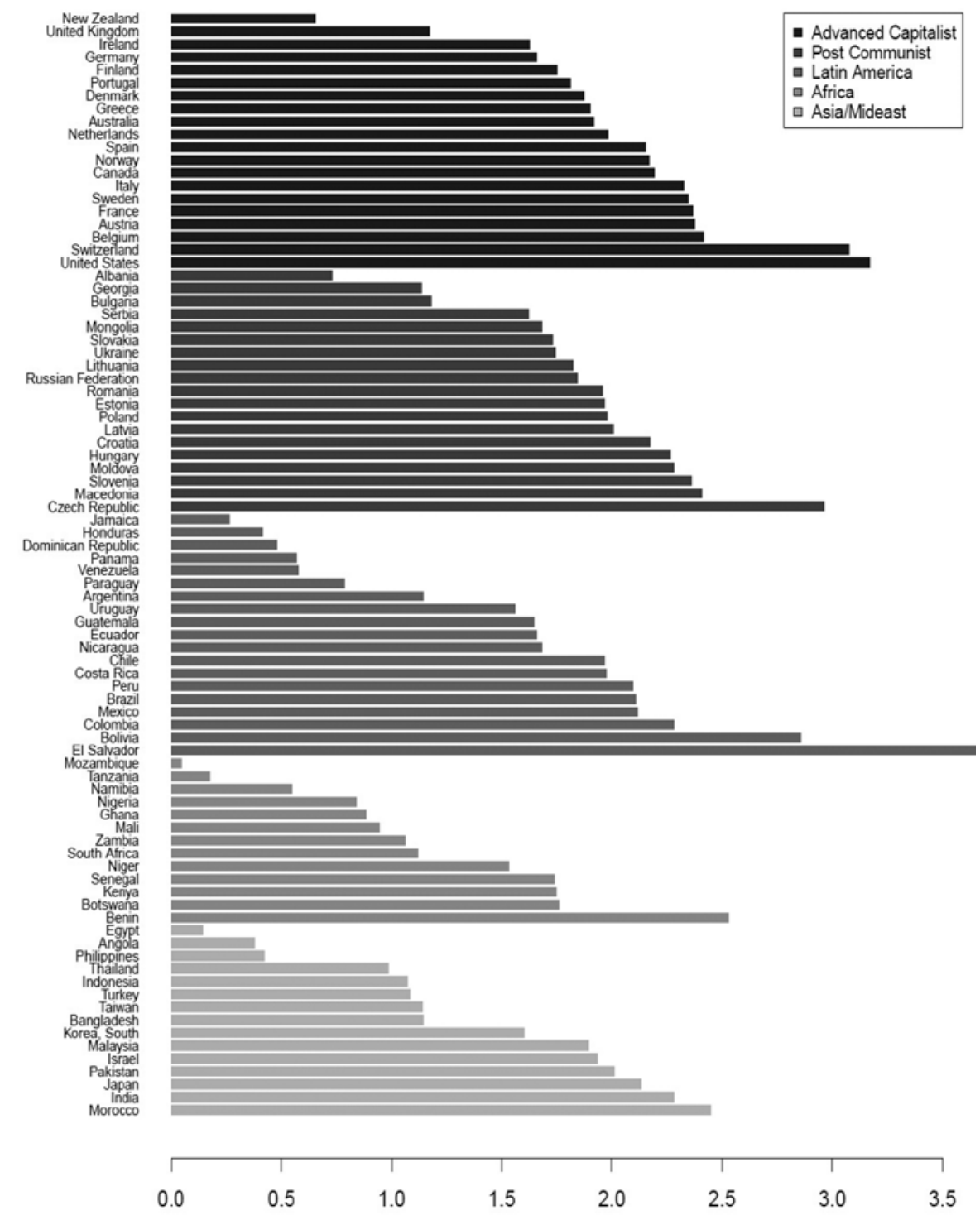

As we expect, those countries where experts show agreement on the parties' left-right positions, also tend to score highly on the importance of programmatic appeals for political competition.

Let us emphasize that a theoretical account of these patterns would have to do a lot more than these simple figures, which are used primarily to establish the concept validity of the indicators. The visual pattern is just a plausibility probe that the data are likely to tap an objective pattern in the real political world rather than a contrived methodological 
Figure 4: Average Standard Deviation of Parties' Left-Right Location and Parties' Programmatic Appeals

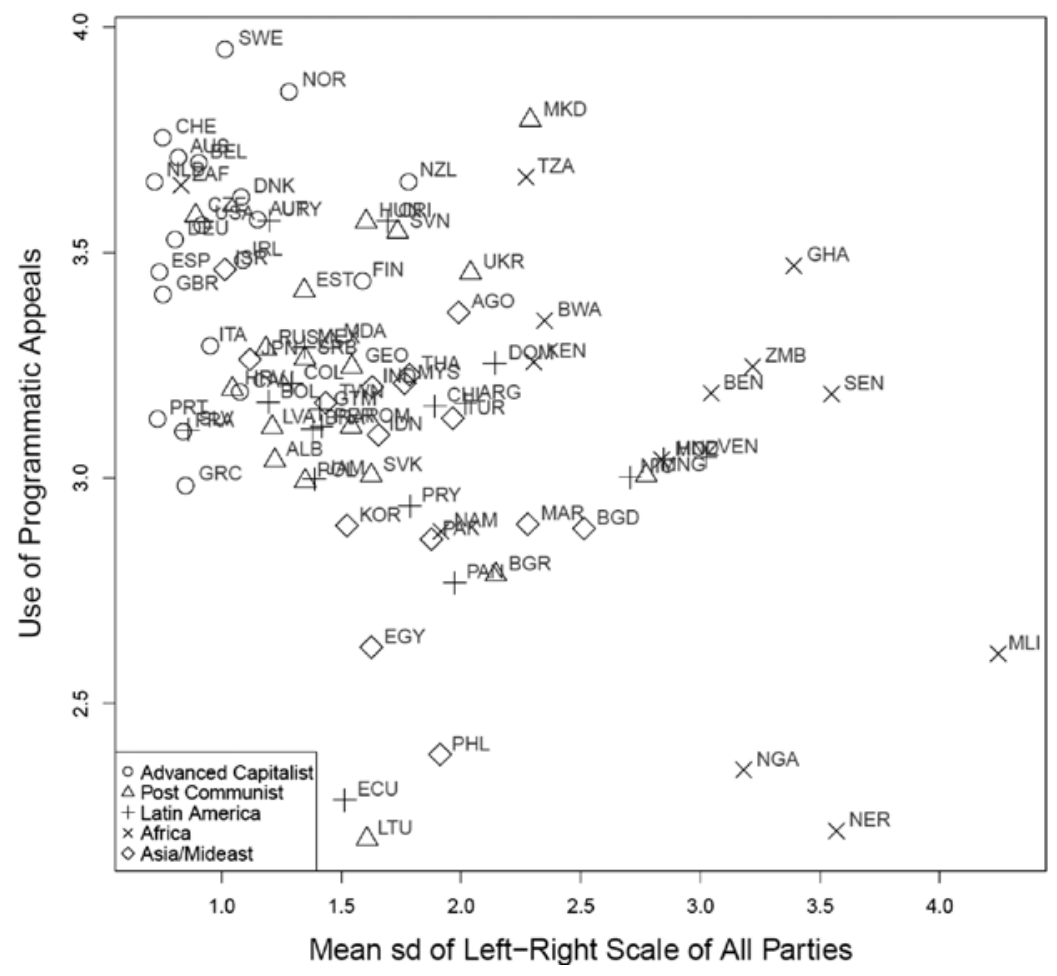

artifact. The various programmatic measures taken from the survey reveal clear patterns in the levels of cross-national programmatic competition.

Beyond a refinement of the trajectory of analysis begun in this paper, there is a great deal to accomplish in the comparative analysis of programmatic structuring. Even before examining the content of the issues and issue dimensions that structure the party systems across the world, it will be important to gauge the extent to which "ideological constraint" shapes competitive spaces with more fine-grained instruments. For example, we can explore the extent to which actual issue positions experts attribute to parties indeed predict experts' left-right placements of the parties. We can then compare the extent to which these within-country statistical relations vary across countries and try to account for differential coefficients in a systematic fashion. We can also engage in factor and discriminant analyses or related statistical techniques to recover unobserved underlying variables that identify competitive spaces in each country and strive to explain the differential strength and content of such underlying factors. Ultimately, a comparison of 90 countries may allow us to achieve some additional insight into the constitution of cleavage dimensions, when compared to Lipset and Rokkan's (1967) classic about Western Europe taken by itself. 


\section{A GLIMPSE AT DATA II: PARTY ORGANIZATION AND ACTION}

A study of party organization is important for a number of reasons some of which were briefly touched upon earlier in this paper. We begin with a simple inspection of both the organizational extensiveness and centralization of parties in different countries, shown in figure 5. For organizational extensiveness, experts were asked to estimate how common it is for parties to have local district offices (question A1) and whether parties maintain ancillary or subsidiary organizations (question A2). Scores in figure 5 are reversed so that higher values indicate greater extensiveness of organization. The level of party centralization is taken from question A4 and A6, regarding the level at which party nominations and strategic decisions are made, with higher values indicating greater party centralization over candidate selection and/or electoral strategies. As with other indicators reported here, these are weighted by electoral support.

In this case, it is quite difficult to draw inferences about the plausibility of measures from a simple visual inspection of these highly aggregate data. At the level of individual parties, we probably should see some relationship between the age of parties and organizational extensiveness. At the systemic level, less fragmented systems should, on average have more extensive party organization. But a lot of other things may go on. In countries with

Figure 5: Organizational Extensiveness and Centralization of Intra-party Control

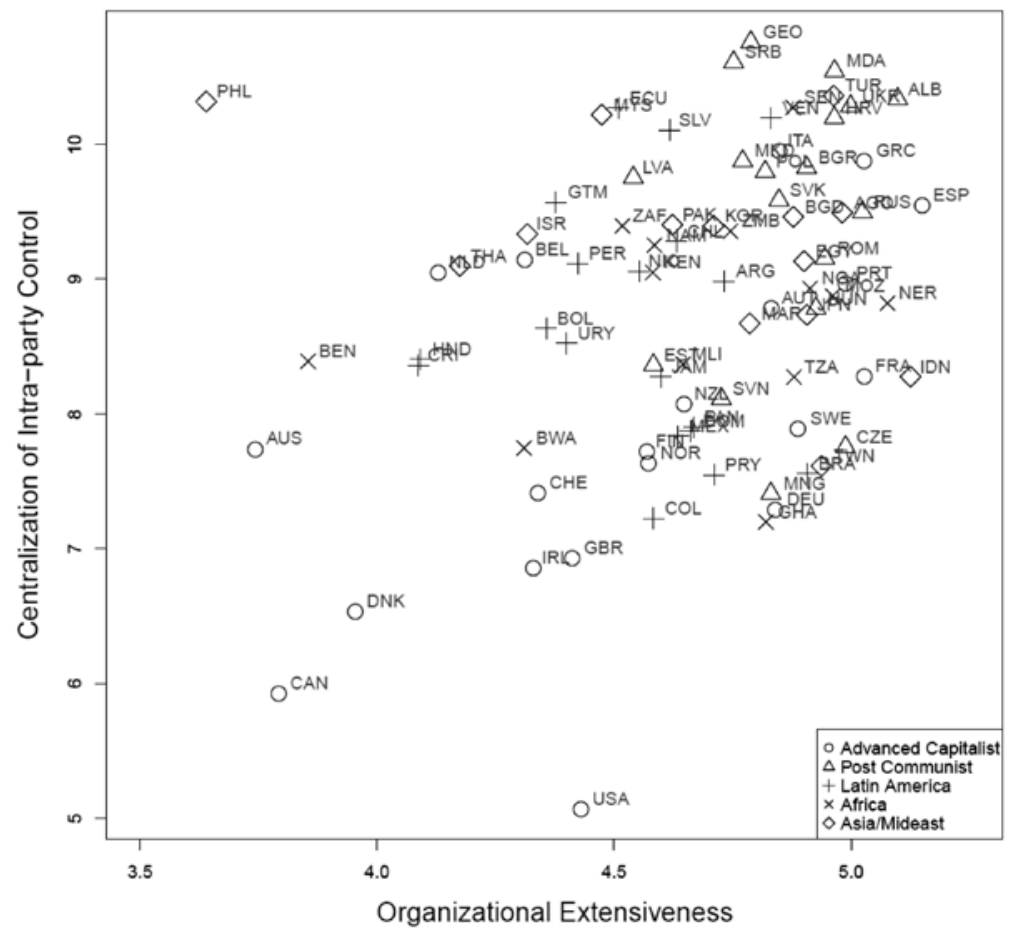


long established party systems, for example, we might expect an effect of institutional arrangements. Party organizations may be weaker where the electoral laws provide for single member or small member districts in a highly decentralized setting. At the opposite extreme of extensive party organization are primarily stable PR-based party systems with large political machines. But the relationship between institutions and party organization is not complete. Almost perfect PR systems in Denmark and the Netherlands clock in with very weak party organization. This may not be a measurement error, as case studies of these countries indicate the collapse of erstwhile encompassing, powerful mass party organization in both countries in the course of "depillarization" of Dutch politics in the 1960s and the drying up of party membership in Denmark in the 1970s and 1980s, decades of high volatility and new party formation.

In Latin America, it is primarily countries with more institutionalized parties and those that went through an ideologically based civil war (Nicaragua, El Salvador) that exhibit more extensive party organization. Less fragmentation also leaves an impact. This impressionistic hypothesis can be extended to the Asia/Middle East group and the results appear to be plausible. What is pretty astounding in the data set is the general tendency of postcommunist countries to be scored as having rather extensive party organization.

The only region of the world where we find at least a modicum of countries where parties have instituted internal decision-making, decentralized features that are approximating democracy with open competition is Western Europe and the Anglo-Saxon democracies. The Mediterranean outliers to this pattern (Greece, Italy, Portugal, Spain) are known to have parties under the spell of strong leaders. Everywhere else in the world parties that offer some input to the rank-and-file are more or less the exception to the rule, a generalization that requires some qualifications only for Sub-Saharan Africa. The most uniformly centralized parties appear in post-communist polities, in Asia and the Middle East, whereas the centralization is somewhat less pronounced in Latin America and varies widely in Sub-Saharan Africa.

One of the hardest topics to research in the comparative study of parties is their political economy of fund raising or party finance. In the construction of this data set, it was a real struggle to come up with questions that would even approximate several baseline criteria, namely that respondents have some knowledge to provide an answer and that the question can be posed in a general way intelligible in different institutional and strategic contexts. A rough summary of two questions, the compliance of parties' fund raising with campaign regulations, is shown in figure 6 . This measures the proportion of respondents who felt that most public and private finance was collected in accordance with campaign finance. Of course, one would have to know how restrictive the regulations are and how arduous compliance is to fully assess the scores, although it is a reasonable presumption that more regulations typically mean more restricted access to unrestrained special interest funding. Our very coarse "dirty" measure, in any case, provides a clearcut pattern showing that restrictive finance legislation and especially compliance with such legislation is almost exclusively a preserve of well-established affluent OECD democracies in Western Europe, Eastern Europe and Asia, with a possible inclusion of some of the East European EU-member states. 
Figure 6: Parties' Private and Public Revenue Collected in Compliance with Regulation

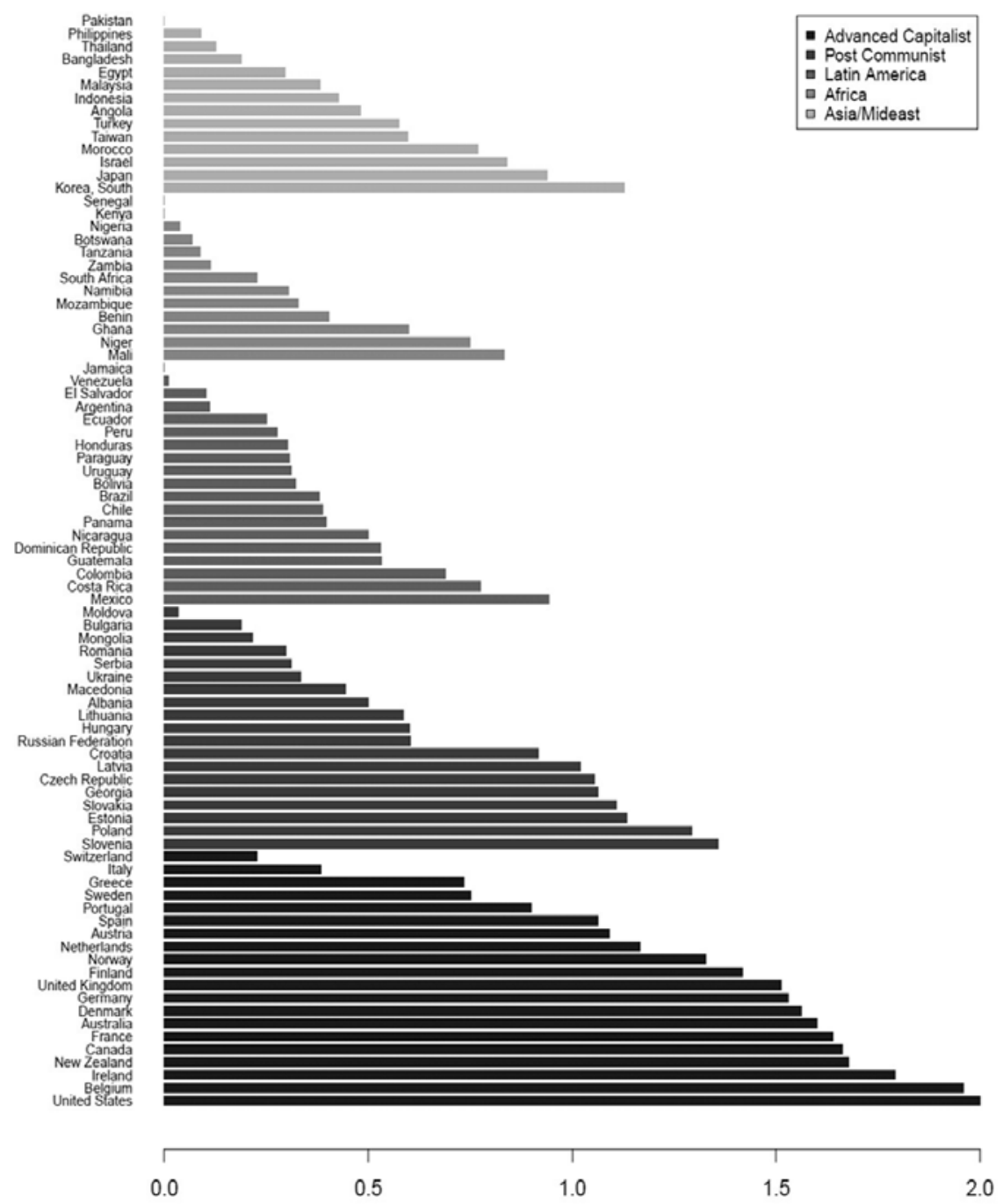

The cross-national distribution of compliance with regulation yields a not implausible result, although there are some individual country scores that are unlikely to be correct in light of the existing case study literature. May we draw the reader's attention to the odd outlier status of Sweden and Switzerland, where campaign compliance is rated as lower than in Niger and Mali? Also, at the other extreme, consider Mexico, according to our experts with the relatively "cleanest" partisan political economy in Latin America, ahead of Colombia, Chile, Brazil, and Costa Rica! Measurement error, in part derived from anchor point heterogeneity, may limit the cross-national comparison of party finance scores. Also outlier parties might drive some of these 
results, an issue addressed by more disaggregate analysis. Nevertheless, the visual and impressionistic inspection of expert scores lets us have less confidence in the party finance measures than those concerning the organizational intensiveness and internal power centralization of parties.

\section{A GLIMPSE AT DATA III: TARGETED EXCHANGE AND MONITORING}

Let us now turn to one of the core concerns of our data set collection and the analytical component where we are reaching out into unchartered territories, namely the assessment of clientelistic exchange relations of targeted goods provision for votes and services to a party. We have particular concerns about anchor point problems here, and therefore included at least one quasi-vignette in the preface to part B of the survey. We distinguish five different classes of targeted goods (questions B1 through B5 in the survey), which we then sum together to create a weighted aggregate measure of clientelistic efforts (range from 5 to 20). The use of targeted goods, however, may or may not effectively turn into votes. As a result, we use another measure indicating the degree to which experts view the use of targeted benefits as directly turning into electoral support. The scattergram of the two variables is shown below in figure 7 .

Figure 7: Parties' Effort to Provide Targeted Benefits and Their Effectiveness to Generate Electoral Support

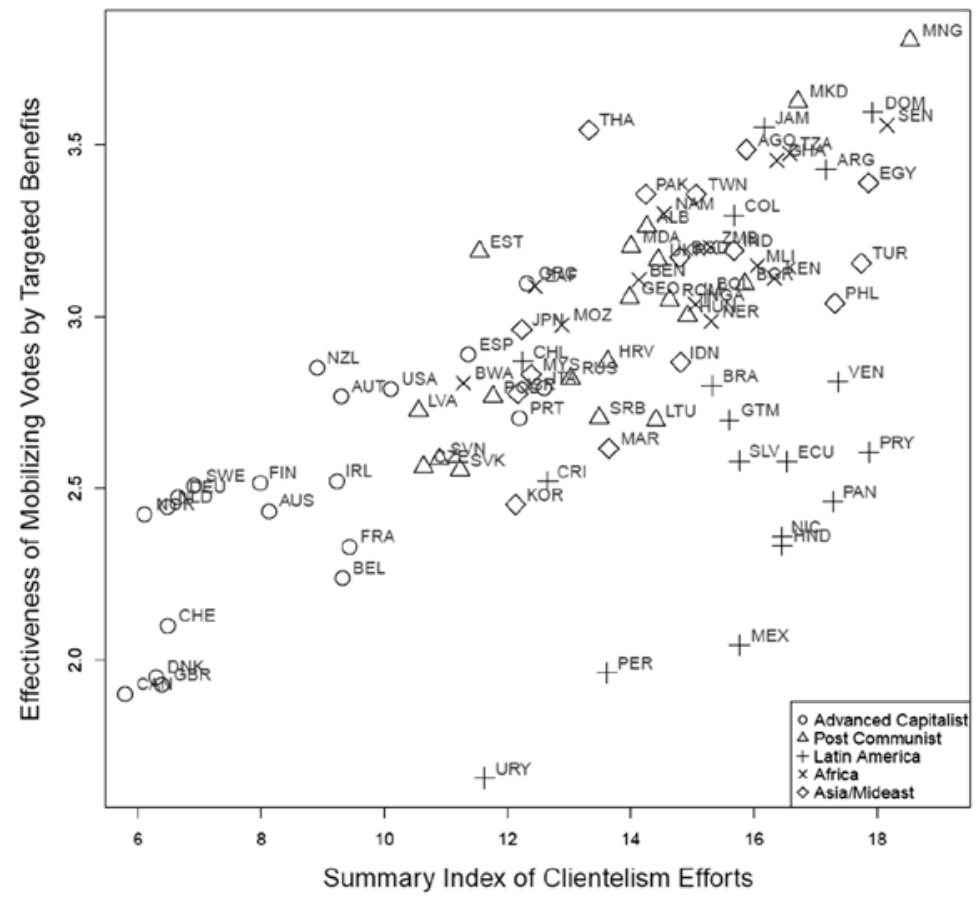


First, to summarize the country-level distribution of targeted benefits, it is in Western OECD countries only that we find politics without targeted exchange. Even here, the "usual suspects" to violate such rules stand out (Italy, Greece, Spain, Portugal). This matches just about perfectly with the case study literature (Kitschelt 2007a). As revealed by figure 7, those countries with parties that expend a large portion of effort on target exchange are also generally more effective at generating votes using this method. However, this is not always the case. In many Latin American countries, such as Mexico, Peru and Panama, experts see the mobilization of targeted resources, but believe that such undertakings are by and large futile. For reasons to be determined, in some countries politicians choose clientelistic exchange strategies, even though voters do not consummate the exchange and decline to deliver their vote, whereas elsewhere a symmetrical relationship between mutual provisions does exist. Indeed, it may be a challenging subject for theoretical and empirical analysis to determine conditions for the effectiveness of clientelistic targeting strategies and for the choice of such strategies, even where they are likely to be futile for vote maximization.

Murkier and more puzzling are the coarse aggregate national scores on the issue of monitoring of clientelistic exchange where experts were asked to assess whether parties have the capacity and actually do try to determine how individuals and small groups of citizens vote (figure 8). Here we have to check first the meaning of the question. Although we framed the question such as to rule out that experts would consider fine-grained opinion polls a reason to consider parties as active and successful in a quest to identify voters, our open-ended question C.3 reveals that in some Western countries (e.g. Canada), respondents gave parties a high effectiveness score precisely because of their use of opinion polls. Without detailed analysis of the meaning of the answers to C.3, it will therefore be unclear if and how the response patterns to question C.1 can be interpreted.

Nevertheless, one robust negative finding stands out that is consistent with experts' response patterns to earlier questions about targeted goods provision and its effectiveness of vote production. In Latin America, experts overwhelmingly score parties as unsuccessful in their quest to determine voters' electoral conduct just as they saw parties as unsuccessful in producing votes with targeted benefits. That is, as experts judged the parties in a country to better monitor voting behavior of citizens, their evaluation of the effectiveness of targeted goods strategies by parties also increased. The strengths of the correlation vary across geographical areas. While the positive correlation is especially strong across SubSaharan African democracies, the correlation across the Western established democracies and post-Communist democracies is more tenuous. How the relations is mediated through other institutional or economic factors may be worth further investigation.

Finally, we can also compare the aggregate targeted goods provision discussed previously with alternative measures of clientelistic competition taken from the survey. Question E.3 asked experts to provide a assessment of the degree to which each party relied on targeted goods provision in the country, which we aggregate to the national level by weighting the average score by electoral support in the past election. The scattergram between this indicator and the summary indicator developed from question B.1 to B.5 is shown in Figure 9. There is a clear and robust correlation between the two variables, increasing 
Figure 8: Monitoring of Voters

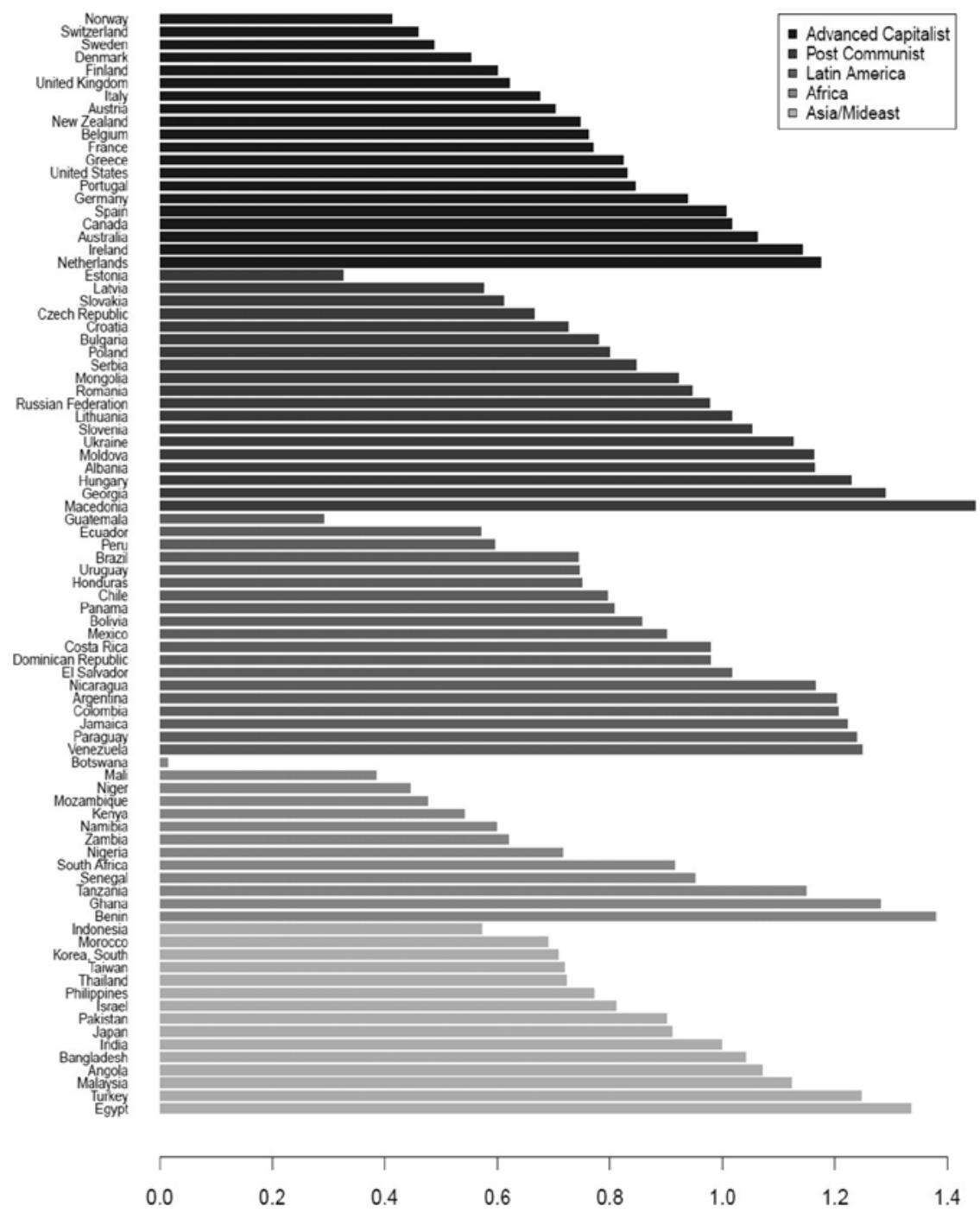

our confidence that the measures of clientelistic competition in the survey are capturing an objective pattern and are not simply artifacts of the data.

\section{CONSTRUCT VALIDATION: LINKAGE STRATEGIES AND THEORETICALLY RELATED CONCEPTS}

While this paper is unable to adequately detail and test theories of democratic linkage strategies, we may give some examples of striking and surely important statistical regularities 
that call for detailed causal explanations. The fact that these striking correlations occur is itself an indication of "construct validity," in the sense that variables constructed from the democratic accountability survey relate to other phenomena in the world to which a causal relationship is plausible, albeit in need of precise specification we cannot deliver here. Table 3 lists seven such relationships. In case of each correlate of linkage strategies, we provide two measures of programmatic competition documented in figure 4 and two measures of clientelism presented in figure 9 .

First, there is a great deal of speculation whether the wealth of polities somehow relates to the linkage strategies prevailing between citizens and politicians. Table 3 , row 1 , suggests that this is indeed the case, with a very robust negative association between economic affluence and clientelistic transactions and a somewhat less powerful positive relationship between affluence and programmatic competition. Second, there is a controversy about the relationship between the quality of democracy in terms of citizens' participation and their civil and political right. There is such a relationship, but it is not very strong, reflecting the divided nature of the debate. Third, political-economic governance structures that protect

Figure 9: Parties' Effort to Provide Targeted Benefits and Their Reliance on Clientelistic Appeals

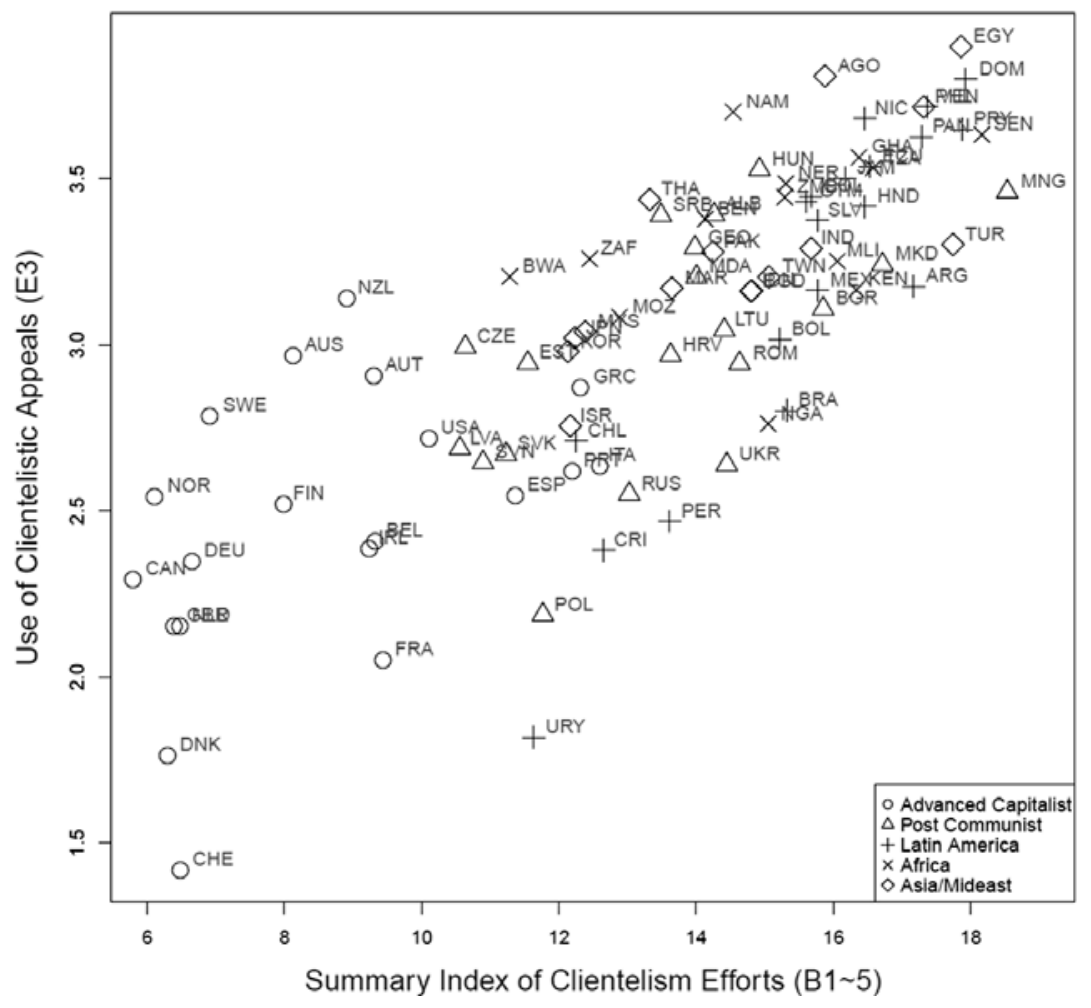


Table 3: Correlates of democratic linkage strategies. Simple bivariate correlations

\begin{tabular}{|c|c|c|c|c|}
\hline & \multicolumn{2}{|c|}{$\begin{array}{c}\text { Clientelistic strategies } \\
\text { (see figure 9) }\end{array}$} & \multicolumn{2}{|c|}{$\begin{array}{l}\text { Programmatic policy } \\
\text { strategies (see figure 4) }\end{array}$} \\
\hline & $\begin{array}{c}\text { Summary } \\
\text { index of } \\
\text { clientelism efforts } \\
(\mathrm{B} 1 \sim 5)\end{array}$ & $\begin{array}{l}\text { Uses of } \\
\text { clientelistic } \\
\text { appeals } \\
\text { (E3) }\end{array}$ & $\begin{array}{c}\text { Uses of } \\
\text { Programmatic } \\
\text { Appeals } \\
\text { (E2) }\end{array}$ & $\begin{array}{l}\text { Mean of standard } \\
\text { deviations of } \\
\text { parties' positions on } \\
\text { the left-right scale }\end{array}$ \\
\hline $\begin{array}{l}\text { 1. Per capita GDP } \\
\text { (average, most recent } \\
\text { five years) }\end{array}$ & -0.86 & -0.68 & +0.49 & -0.65 \\
\hline $\begin{array}{l}\text { 2. Quality of Democracy } \\
\text { (Polity II) }\end{array}$ & -0.44 & -0.48 & -0.33 & -0.36 \\
\hline $\begin{array}{l}\text { 3. Rule of Law } 2006 \\
\text { (World Bank Gover- } \\
\text { nance Indicator) }\end{array}$ & -0.87 & -0.64 & +0.54 & -0.55 \\
\hline $\begin{array}{l}\text { 4. Corruption (World } \\
\text { Bank Governance }\end{array}$ & & & & \\
\hline Indicator) & -0.90 & -0.68 & +0.58 & -0.55 \\
\hline $\begin{array}{l}\text { 5. Inclusiveness of social } \\
\text { policy (Bertelsmann } \\
\text { Transformation Index) }\end{array}$ & -0.55 & -0.45 & +0.27 & -0.60 \\
\hline $\begin{array}{l}\text { 6. Interpersonal Trust } \\
\text { (World Values Studies } \\
\text { and Regional Values }\end{array}$ & & & & \\
\hline $\begin{array}{l}\text { Studies) } \\
\text { 7. Preference for } \\
\text { democracy as best } \\
\text { regime (World Values }\end{array}$ & $-0.80^{\mathrm{a}}$ & $-0.58^{\mathrm{a}}$ & $+0.49^{\mathrm{a}}$ & -0.40 \\
\hline & $-0.42^{\mathrm{a}}$ & -0.33 & $+0.35^{\mathrm{a}}$ & -0.27 \\
\hline
\end{tabular}

${ }^{a}$ Correlations with interpersonal trust or preference for democracy that remain statistically significant at conventional levels (.05), even when a polity's affluence (GDP per capita) and democratic quality (Polity II) are controlled for.

the security of property rights may be related to politicians' choice of linkage strategies. Again, the correlations in rows 3 (rule of law) and 4 (corruption) with the World Bank Governance indicators bears out this hunch, albeit in a way that requires a great deal of probing. Fifth, there are expectations that some linkage strategies provide more social benefits than others, and indeed, this appears to be borne out in a negative way for the relationship between the comprehensiveness of social policies that protect people from the vagaries of the labor market and clientelism. Once again, programmatic linkage strategies display a less tight association. 
Sixth, linkage mechanisms may also affect people's interpersonal trust and, indeed, this appears to be borne out quite strongly at the level of aggregate cross-national comparison (row 6). Finally, people's judgments of the desirability of democracy may be affected by their daily experiences with democratic accountability mechanisms and, indeed, this expectation appears to be borne out, yet in a rather feeble way (row 7). People's sense of interpersonal trust and allegiance to democracy indeed interacts with national practices of democratic accountability. Nevertheless, this relationship is complicated and possibly mediated.

\section{CONCLUSION}

This paper marks the beginning, not the conclusion of a most likely lengthy trajectory of future research and analysis. But it is worth embarking on this undertaking only if now, after an effort of more than four years, we are able to determine that the data we are dealing with are actually worth taking seriously. For this reason, a wide variety of validity checks is in order. Our paper takes only the first step of even this preliminary exercise, and we hope to obtain feedback from readers to make that exercise more rigorous in order to arrive at fairly robust conclusions.

The project has been motivated by the need of quantitative estimates of modes of democratic accountability for cross-national comparative research. In this cross-national data set, party-level and polity-level data on party organization, practices of targeted exchange, monitoring of compliance with contingent exchange, policy position, and the general linkage mechanisms are collected through expert survey. Some methodological challenges which may impair the data quality are pointed out. These potential problems are caused by limited expertise of the experts, the processes of aggregation of data to higher level, the anchor point problem as scores might not be comparable across experts/countries, and the bias of the experts. Some procedures to check the data quality are also discussed in the paper. To conduct these procedures, we present the national average scores of some variables to show the patterns of variance, the patterns of non-responses, and the univariate distribution of these variables across geographical areas.

With all of the methodological issues, and possible sources of bias in this expert survey, and the overly simplistic data methods utilized, in many respects, we have put our "worst foot" forward in this paper. Despite this, we were able to find cross-national variance in many of the questions asked in the survey, and in the general direction we would expect given the case studies literature on the topic. Though the lack of disaggregation might blur the patterns in the data, the national scores we present show a semblance of plausibility. The correlations between them also provide some evidence of validity and potential theoretical relations among concepts. Of course to more adequately assess the quality of the data set, further steps will be needed and methodological issues dealt with. These steps may include examining within-party variance across variables, conducting external validity tests for the indicators which were also measured in other studies, and inspecting correlations among other measures in the data set to assess the construct validity. 


\section{REFERENCES}

Benoit, Kenneth, and Michael Laver. 2006. Party Policy in Modern Democracies. London: Routledge.

Calvo, Ernesto, and M. Victoria Murillo. 2004. "Who Delivers? Partisan Clients in the Argentine Electoral Market". American Journal of Political Science 48 (4): 742-57.

Chandra, Kanchan, and Steven Wilkinson. 2008. "Measuring the Effect of 'Ethnicity.'” Comparative Political Studies 41 (4/5): 515-63.

Downs, Anthony. 1957. An Economic Theory of Democracy. New York: Harper and Row.

Duch, Raymond N., and Randoph T. Stevenson. 2008. The Economic Vote. How Political and Economic Institutions Condition Election Results. Cambridge: Cambridge University Press.

Erickson, Robert S., Michael B. MacKuen, and James A. Stimson. The Macro Polity. Cambridge: Cambridge University Press.

Fiorina Morris. 1981.Retrospective voting in American elections. New Haven Yale University Press.

Gabel, Matt J., and John D. Huber. 2000. "Putting Parties in Their Place: Inferring Party Left-Right Ideological Positions from Party Manifestos Data". American Journal of Political Science 44 (1): 94-103.

Hawkins, Kirk and Guillermo Rosas. 2007. “Turncoats, True Believers, and Turnout. Machine Politics in an Australian Ballot System". Unpublished paper. University of Washington and Brigham Young University.

Hinich, Melvin J. and Michael C. Munger. 1994. Ideology and the Theory of Political Choice. Ann Arbor: Michigan University Press.

Keefer, Philip. 2006. Clientelism, Credibility, and the Policy Choices of Young Democracies. Mimeo World Bank.

King, Gary, Christopher J. L Murray, Joshua A. Salomon, and Ajay Tandon. 2004. "Enhancing the Validity and Cross-Cultural Comparatibility of Measurement in Survey Research". American Political Science Review 98 (1): 191-207.

King, Gary, and Jonathan Wand. 2007. "Comparing Incomparable Survey Responses: Evaluating and Selecting Anchoring Vignettes". Political Analysis 15 (1): 46-66.

Kitschelt, Herbert. 2000. "Linkages Between Citizens and Politicians in Democratic Polities," Comparative Political Studies 33 (6-7): 845-879.

Kitschelt, Herbert. 2007a. "The Demise of Clientelism in Affluent Capitalist Democracies". In Herbert Kitschelt and Steven Wilkinson, eds. Patrons, Clients, and Policies. Pp. 298-321. Cambridge: Cambridge University Press.

Kitschelt, Herbert. 2007b. "Party Systems". in Carles Boix and Susan Stokes, eds., Handbook of Comparative Politics. Pp. 522-554. Oxford: Oxford University Press.

Kitschelt, Herbert, and Steven Wilkinson. (Eds.). 2007. Patrons, Clients, and Policies. Cambridge: Cambridge University Press.

Kitschelt, Herbert, and Steven Wilkinson. 2007a. "Citizen-Politician Linkages: An Introduction". In ibíd., eds. Patrons, Clients, and Policies. Pp. 1-49. Cambridge: Cambridge University Press.

Laver, Michael, Kenneth Benoit, and John Garry. 2003. “Extracting Policy Positions from Political Texts Using Words as Data". American Political Science Review 97 (2): 311-31.

Laver, Michael, and V. Ben Hunt. 1992. Policy and Party Competition. London: Routledge and Kegan Paul.

Lipset, Seymour Martin, and Stein Rokkan. 1967. "Cleavages Structures, Party Systems, and Voter Alignments. An Introduction". In Lipset and Rokkan, eds., Party Systems and Voter Alignments. CrossNational Perspectives, pp.1-64. New York: Free Press.

Magaloni, Beatriz, Alberto Diaz-Cayeros, and Federico Estevez. 2007. "Clientelism and Portfolio Diversification: A Model of Electoral Investment with Applications to Mexico". In Herbert Kitschelt and Steven Wilkinson, eds. Patrons, Clients, and Policies. Pp. 182-205. Cambridge: Cambridge University Press

Marks, Gary, Liesbet Hooghe, Marco R. Steenbergen, and Ryan Bakker. 2007. "Crossvalidating Data on Party Positioning on European Integration". Electoral Studies 26 (1): 23-38. 
Medina, Luis Fernando, and Susan Stokes. 2007. "Monopoly and Monitoring. An Approach to Political Clientelism". In Herbert Kitschelt and Steven Wilkinson, eds. Patrons, Clients, and Policies. Pp. 68-83. Cambridge: Cambridge University Press.

Nichter, Simeon. 2008. "Vote Buying or Turnout Buying. Machine Politics and the Secret Ballot". American Political Science Review 102 (1): 19-31.

Piattoni, Simona. (Ed.). 2001. Clientelism, interests, and democratic representation. Cambridge: Cambridge University Press.

Putnam, Robert D. 1993. Making Democracy Work. Civic Traditions in Modern Italy. Princeton, N.J.: Princeton University Press.

Rehm, Philipp. 2008. The Manifesto Data Set. Some Critical Remarks. Paper presented at the Workshop on New Methods in Comparative Politics, Duke University, April 2-3.

Rohrschneider, Robert, and Stephen Whitefield. 2009. "Understanding Cleavages in Party Systems. Issue Positions and Issue Salience in 13 Postcommunist Democracies". Comparative Political Studies 42 (2): 280-313.

Sartori, Giovanni. 1976. Parties and Party Systems. A Framework for Analysis. Cambridge: Cambridge University Press.

Shefter, Martin. 1977. "Party and Patronage: Germany, England, and Italy". Politics and Society 7 (3): 403-51.

Stokes, Susan. 2005. "Perverse Accountability. A Formal Model of Machine Politics with Evidence from Argentina," American Political Science Review 99 (2): 315-327.

Herbert Kitschelt (E-mail: h3738@duke.edu) is George V. Allen Professor of International Relations in the Political Science Department at Duke University, North Carolina, USA. Kitschelt has published numerous books and articles on parties and party systems in Western Europe, Eastern Europe, and recently Latin America (Herbert Kitschelt, Kirk Hawkins, Juan Pablo Luna, Guillermo Rosas and Elizabeth Zechmeister. 2010. Latin American Party Systems. Cambridge: Cambridge University Press).

Kent Freeze (E-mail: kent.freeze@duke.edu)

Kiril Kolev (E-mail: kiril.kolev@duke.edu)

Yi-Ting Wang (E-mail: yw48@duke.edu) are doctoral candidates in the Political Science Department at Duke University. 
